\title{
Transporting live silver catfish (Rhamdia quelen) with salt addition does not mitigate fish stress and negatively affects meat quality
}

\author{
Sheron Scholze ROSA ${ }^{1}$, Ana Paula BALDAN ${ }^{1}$, Fabiano BENDHACK ${ }^{2}$, Aline Fernanda Lopes PASCHOAL ${ }^{1}$, \\ Ananda Leticia Almeida CORDEIRO ${ }^{2}$, Peter Gaberz KIRSCHNIK ${ }^{3}$, Tâmara Duarte BORGES ${ }^{1}$ (D), \\ Renata Ernlund Freitas MACEDO ${ }^{1 \star}$
}

\begin{abstract}
This study evaluated the effects of $\mathrm{NaCl}$ added to water during silver catfish (Rhamdia quelen) transportation on stress and meat quality. Physiological indicators of stress (cortisol, glucose, circulating ions and liver glycogen) and meat quality parameters (rigor mortis, $\mathrm{pH}$, instrumental color, psychotropic aerobic count and sensory analysis) were assessed. Adult silver catfish $(\mathrm{n}=380)$ were distributed in four experimental groups: T1: non-transported; T2: transported without $\mathrm{NaCl}$ water addition; T3: transported with $8.0-\mathrm{g} \mathrm{NaCl} \mathrm{L}^{-1}$ water addition; T4: transported with $12.0-\mathrm{g} \mathrm{NaCl} \mathrm{L}^{-1}$ water addition. The addition of $\mathrm{NaCl}$ was not effective at reducing blood cortisol in silver catfish $(P>0.05)$. An osmotic imbalance was detected as an increase in sodium and calcium levels in the $\mathrm{NaCl}$ treatment groups. The $12.0-\mathrm{g} \mathrm{NaCl} \mathrm{L}^{-1}$ treatment showed rigor mortis evolution in lesser time than the other treatments, and also presented redder meat color. The $\mathrm{NaCl}$ addition in transport water do not mitigate the stress in silver catfish, and in high concentrations $\left(12.0-\mathrm{g} \mathrm{L}^{-1}\right)$ was unfavorable for the homeostasis of fish and have negatively affected its meat quality.
\end{abstract}

Keywords: homeostasis; $\mathrm{NaCl}$; cortisol; water.

Practical Application: $\mathrm{NaCl}$ in transport did not mitigate stress and negatively affected meat quality of silver catfish.

\section{Introduction}

Among the native species, silver catfish (Rhamdia quelen) is noteworthy in Brazil. This catfish is of South American origin (Pereira et al., 2006) and has characteristics that favor its use for farming, which include high resistance, docility and adaptability to various diets and different cultivation systems. Furthermore, it is widely accepted by the consumer market due to favorable sensory properties of its meat, which is flavorful, provides lean fillets, has no intramuscular bones, and has a good texture (Carneiro et al., 2004; Fracalossi et al., 2004).

Transportation of live fish is a very important stage of production chain, given that they need to arrive at their final destination under satisfactory conditions, meeting the standards demanded by consumers. During transport, fish may experience adverse effects of stress, which impairs the quality of their meat (Food and Agriculture Organization of the United Nations, 1986). To mitigate stress during live fish transportation, the addition of natural sedatives such as essential oils (Becker et al., 2012) or osmoregulatory salts such as sodium or calcium chloride (Bendhack \& Urbinati, 2009) in the transport water have been reported. The addition of sodium chloride $(\mathrm{NaCl})$ in transport water has shown positive effects in neotropical species such as matrinxã (Brycon amazonicus) (Carneiro \& Ubinati, 2001) and tambaqui (Colossoma macropoun) (Gomes et al., 2003). This procedure helps to maintain the osmoregulatory balance of the fish and $\mathrm{NaCl}$ also acts prophylactically and stimulates the secretion of mucus from the branchial epithelium (Food and Agriculture Organization of the United Nations, 1986; McDonald \& Milligan, 1997).

The success of salt addition depends on fish species and the life stage. To juveniles silver catfish, addition of $\mathrm{NaCl}$, did not mitigated stress during transportation (Gomes et al., 1999). However, there are no reports on the effects of $\mathrm{NaCl}$ on water transport of adults silver catfish. The objective of this study was to evaluate the stress-mitigating effect of different concentrations of $\mathrm{NaCl}$ added to transport water of adult silver catfish (R. quelen) and their impact on the meat quality.

\section{Material and methods}

Ethical and biosafety aspects of this study were performed in accordance with Resolution $n^{\circ} 196 / 96$ of National Board of Health/National Research Ethics Committee and were approved by Ethics Committee on Animal Use (CEUA) of PUCPR, statement $\mathrm{n}^{\circ} 719$.

\subsection{Animals, experimental conditions and sampling}

Forty-eight hours before transportation, feeding (commercial diet containing 32\% crude protein, SUPRA, Alisul Alimentos, São Leopoldo, RS, Brazil) was interrupted to ensure the fish 
had an empty intestinal-tract in order to maintain water quality during transport. For fish catching, the water of an earth pond $\left(400 \mathrm{~m}^{2}\right)$ was partially drained, and silver catfish were subsequently captured using trawls and dip nets.

For the experiment, 380 adult silver catfish with mean length of $25.9 \pm 2.1 \mathrm{~cm}$ and average weight of $360.0 \pm 99 \mathrm{~g}$, from an excavate-pond culture, were used. For each treatment, 95 fish were used and four experimental groups were considered: Non-transported (post-net-casting); transported without $\mathrm{NaCl}$ addition to water; transported with 8.0 -g common $\mathrm{NaCl} \mathrm{L}^{-1}$ dissolved in water; transported with 12.0 -g common $\mathrm{NaCl} \mathrm{L}^{-1}$ dissolved in water.

Transported groups were conditioned in 250-L transporting units at density of $150 \mathrm{~kg} \cdot \mathrm{m}^{-3}$, fitted in a truck. Oxygen was supplemented by a cylinder and diffusion hoses regulated with a flow of $2 \mathrm{mg} \mathrm{O} \mathrm{L}^{-1} \cdot \mathrm{min}^{-1}$. The transport time was $3 \mathrm{~h}$ on highways in region of São José dos Pinhais - PR, Brazil, the place of departure and arrival was the Laboratory of Fish Farming Research (LAPEP-PUCPR). Experiment was repeated twice.

\subsection{Water sampling and analysis}

Water quality in the pond and in the transport units was analyzed. Dissolved oxygen $\left(\mathrm{mg} \cdot \mathrm{L}^{-1}\right)$, temperature $\left({ }^{\circ} \mathrm{C}\right), \mathrm{pH}$, and total ammonia $\left(\mathrm{mg} \cdot \mathrm{L}^{-1}\right)$ were measured before and after transport in all transport units. At net casting point, the parameters were measured once, directly in the pond.

\subsection{Physiological analyses}

For the physiological analyses (plasma glucose, liver glycogen, serum cortisol, sodium, chloride, potassium, and calcium ions) of 10 fish were collected from each treatment group. The fish were anesthetized in water with benzocaine $\left(60 \mathrm{mg} \cdot \mathrm{L}^{-1}\right)$. Once anesthesia was established ( $3 \mathrm{~min}$.), blood sampling, biometric measurements, and liver harvesting began. Blood was drawn from the fish by caudal venipuncture, divided into two aliquots, and stored in collection tubes $(1.5 \mathrm{~mL})$. Anti-glycolysis-anticoagulant fluoride EDTA (GLISTAB, Labtest, Lagoa Santa, MG, Brazil) was used in the first tube $(16 \mu \mathrm{L} \mathrm{mL})$ to harvest plasma for later use to determine glucose levels. The blood was immediately centrifuged at $2,991 \mathrm{~g}$ for $10 \mathrm{~min}$ at $10^{\circ} \mathrm{C}$ to enable plasma isolation. A volume of $100-\mu \mathrm{L}$ plasma was deposited into collection tubes and stored at $-18{ }^{\circ} \mathrm{C}$ until further analysis.

The remaining blood was stored at room temperature for $60 \mathrm{~min}$ to allow coagulation. Subsequently, samples were centrifuged at $2,991 \mathrm{~g}$ for $10 \mathrm{~min}$ at $10^{\circ} \mathrm{C}$ to harvest the serum, which was separated into collection tubes at $100-\mu \mathrm{L}$ per tube and stored at $-80{ }^{\circ} \mathrm{C}$ for later determination of cortisol and ion concentrations (chloride, sodium, potassium, and calcium).

After blood collection, the fish were weighed on a digital scale (Q-510-1500, Quimis, Diadema, SP, Brazil) and their lengths were measured using a measuring board (Aquatic Eco System, US). Next, animals were euthanized by spinal cord section. To harvest the liver, fish were opened ventrally with scissors, forceps, and a scalpel. After the abdomen was opened, organs were separated and ligaments were ruptured until the liver was completely free and was not fragmented. The collected livers were weighed, wrapped in foil, rapidly frozen on dry ice and stored at $-80{ }^{\circ} \mathrm{C}$, where they remained until glycogen concentration was determined.

Serum cortisol levels were determined by microplate enzyme immunoassay (DRG Cortisol $^{\circledR}$; ELISA), according to the manufacturer's instructions, and were subsequently read in an automatic plate reader (ELISA, BioTek ${ }^{\circledR}$, Vermont, US). The intra-assay coefficient of variation (CV) was $5.84 \%$ and the inter-assay CV was 7.19\%.

Plasma glucose was quantified by glucose-oxidase enzymatic colorimetric method, using a commercial glucose kit (Analisa, Lagoa Santa, MG, Brazil), according to the manufacturer's instructions, and read in a spectrophotometer (BIOSPECTRO SP-22, Curitiba, PR, Brazil).

Liver glycogen was determined by the method described by Moon et al. (1989). Concentrations of serum sodium, potassium, and calcium were quantified by an ion selective electrode (ISELAB, Drake, São José do Rio Preto, SP, Brazil). The chloride concentration was determined by an enzymatic colorimetric method using a commercial kit, according to the manufacturer's instructions (BIOCLIN ${ }^{\circledR}$, Belo Horizonte, MG, Brazil), and measurements were made by a spectrophotometer (BIOSPECTRO SP-22, Curitiba, PR, Brazil).

\subsection{Meat quality analyses}

The fish were subjected to ice thermal shock and stored in cold boxes containing ice at a ratio of 1:1 (fish/ice), which was constantly replenished. The fish were stored for 10 days to allow the meat quality parameters to be evaluated at pre-defined intervals, as follows:

\section{Muscle $p H$}

Measured in triplicate at $0,1,2,4,6,8,12,18,24,48,96,144$, 192 , and $240 \mathrm{~h}$ postmortem, using a portable digital $\mathrm{pH}$ meter (HOMIS, Belenzinho, São Paulo, SP, Brazil) with an electrode inserted directly into the epaxial muscle, adjacent to the dorsal fin (three fish for each treatment at each sampling time);

\section{Rigor Mortis Index (RMI)}

Measured in triplicate at $0,4,8,12,16,18,20$, and $24 \mathrm{~h}$ postmortem, using the same fish at each time interval (five fish for each treatment). The rigor mortis index was determined according to the method described by Bito et al. (1983). The previously numbered fish were each placed on a flat surface, supported up to the level of the pelvic fins, with the caudal part suspended. The length of the slope that was formed with the surface was measured with a ruler and a set square. The R.M.I was determined by the following formula: R.M.I $(\%)=(\mathrm{D} 0-\mathrm{D}) \times \mathrm{D}^{-1} \times 100$, where $\mathrm{D} 0=$ the initial distance from the base of the caudal fin to the reference point, as measured immediately after death; and $\mathrm{D}=$ distance from the base of the caudal fin to the reference point, at each time points. 


\section{Instrumental color}

Measured in triplicate at $0,48,96,144,192$, and $240 \mathrm{~h}$ postmortem. This variable was determined directly on the surface of the whole fillet collected from the white epaxial muscle adjacent to the dorsal fin (three fish for each treatment at each sampling time); using a portable colorimeter (MINOLTA, CR 410, Tokyo, Japan), illuminant $\mathrm{C}$, an aperture of $50 \mathrm{~mm}$, and $2^{\circ}$ observer. Values were expressed using the CIE coordinates $\mathrm{L}^{\star}$ (lightness), $\mathrm{a}^{\star}$ (redness), $\mathrm{b}^{\star}$ (yellowness), $\mathrm{C}^{\star}$ (chroma) and $\mathrm{h}$ (hue).

\section{Microbiological analysis}

Measured in duplicate at $0,48,96,144,192$, and $240 \mathrm{~h}$ postmortem. Ten (10) g of skinless white epaxial muscle of fish (three fish for each treatment at each sampling time) were aseptically dissected, mixed with $90.0 \mathrm{~mL}$ of $0.1 \%$ peptone water (KASVI, Liofilchem, Roseto, Italy), and homogenized in an aseptic homogenizer (Stomacher ${ }^{\circledR}$ ) for $1.0 \mathrm{~min}$. Serial dilutions from the suspensions were prepared in $0.1 \%$ peptone water and plated on Plate Count Agar - PCA (HIMEDIA M091, Mumbai, India). Plates were incubated at $17^{\circ} \mathrm{C}$ for $16 \mathrm{~h}$, and then incubated $4^{\circ} \mathrm{C}$ for $72 \mathrm{~h}$ for subsequent counting of colonies (Brasil, 2003). Results are expressed as $\log \mathrm{CFU} \cdot \mathrm{g}^{-1}$ of sample.

\section{Sensory analysis}

Performed at $0,48,96,144,192$, and $240 \mathrm{~h}$ postmortem by a staff of 11 evaluators trained in the use of structured five-point scales for the following freshness attributes, using three fish for each treatment at each sampling time:

- Appearance of the eyes (1 - opaque, milky color, sunken, hardly visible pupil; 2 - slightly sunken, loss of brightness, slight opacity; 3 - loss of brightness, slightly sunken, beginning of opacity; 4 - protruding, bright, transparent, black pupil; 5- Highly protruding, bright, transparent, black pupil).

- Body firmness (1 - soft and sinks under finger pressure, no return of the skin; 2 - starts to lose firmness and sink under finger pressure; 3 - still firm to finger pressure; 4 - Firm; 5 - pliable to finger pressure).

- Odor (1 - extremely rancid; 2 - rancid; 3 - of fresh fish but stronger; 4 - of fresh fish but stronger; 5 - mild, hardly noticeable, of fresh fish).

Fish were coded with three random codes and placed on a surface with a white background under a fluorescent light bulb (TLD 32W model, Philips, Capuava, SP, Brazil) that was $2 \mathrm{~m}$ away from the samples.

\subsection{Statistical analysis}

Statgraphics ${ }^{\circledR}$ Centurion XVI version 16.1.11 (Statpoint Technologies, Warrenton, Virginia, USA) was used for statistical analysis of the data.

The physiological data were analyzed by one-way ANOVA and means were compared by Tukey test $(P<0.05)$. The meat quality parameters results were analyzed using a random block design, considering a mixed linear model including treatment and storage time as fixed effects. In cases where the interaction among treatment and storage was not significant $(P>0.05)$, interaction was removed from the model and the main effects were analyzed. Means were compared by Tukey test $(P<0.05)$.

\section{Results and discussion}

\subsection{Physiological parameters}

Water quality parameters were satisfactory to the silver catfish species during all experimental period. The $\mathrm{pH}$ of the water in the earth pond was numerically higher than those of transport units, however $\mathrm{pH}$ of water is considered normal for the region where the Laboratory of Fish Farming Research is located (Carneiro \& Mikos, 2005) and did not affect the growth of catfish (Copatti et al., 2011). Before and after transportation, the $\mathrm{pH}$ mean values remained acceptable to the catfish species (Golombieski et al., 2003), contributing to the non-occurrence of fish lethargy or mortality during the experimental period (Table 1).

No significant difference was found in serum cortisol levels among treatments (Figure 1), with mean values varying between $157.0 \mathrm{ng} \cdot \mathrm{mL}^{-1}$ and $175.0 \mathrm{ng} \cdot \mathrm{mL}^{-1}$. Before transportation, fish showed increased cortisol levels, demonstrating an initial stress response to the catching procedure. Cunha et al. (2010) evaluated cortisol in silver catfish and found that basal levels were lower than $20 \mathrm{ng} \cdot \mathrm{mL}^{-1}$ in control group. An elevated blood cortisol (corticosteroid hormone) level is considered as the main response to stress (Wedemeyer et al., 1990). According to Barcellos et al. (1997), capture procedures, conditioning and subsequent transportation of fish might be stressful to the animals leading to an increase in cortisol levels.

Thus, addition of $\mathrm{NaCl}$ to transport water was not effective at reducing blood cortisol $(P>0.05)$ in silver catfish. Reports on the effect of $\mathrm{NaCl}$ addition in transport water on cortisol levels in fish are species-dependent. Similarly to the present study, Brandão et al. (2008) and Gomes et al. (2006) did not found significant differences in plasma cortisol levels in pirarucu (Arapaima gigas) juveniles transported in water containing $\mathrm{NaCl}$. Therefore, these authors did not observe a reduction in transport-induced stress. In contrast, Urbinati \& Carneiro (2006)

Table 1. Water parameters at earth pond, before and after transport $(3 \mathrm{~h})$.

\begin{tabular}{lcrr}
\hline \multicolumn{1}{c}{ Parameter } & Earth Pond & Before $^{1}$ & \\
\hline $\mathrm{pH}$ & 8.10 & $7.48 \pm 0.33$ & $7.60 \pm 0.50$ \\
Dissolved oxygen $\left(\mathrm{mgL}^{-1}\right)$ & 5.40 & $5.00 \pm 0.22$ & $3.50 \pm 0.31$ \\
Temperature $\left({ }^{\circ} \mathrm{C}\right)$ & 22.50 & $19.60 \pm 0.00$ & $19.80 \pm 0.00$ \\
Total ammonia $(\mathrm{mgL}-1)$ & 0.13 & $0.00 \pm 0.01$ \\
\hline
\end{tabular}

${ }^{1}$ Values are treatment means $\left(0,8.0,12.0-\mathrm{g} \mathrm{NaCl} \mathrm{L}^{-1}\right) \pm \mathrm{SD}$. 
observed that the plasma cortisol levels in matrinxã (Brycon amazonicus) were lower in fish transported in water containing 0 and $1 \mathrm{~g} \mathrm{NaCl} \mathrm{L}^{-1}$ than in those prior to transportation.

The glucose values remained low under all treatments (Figure 1). An increase in plasma glucose is a secondary effect to stress response in fish. According to Brandão et al. (2008) an immediate increase in glucose in response to stress is caused by the secretion of catecholamines, especially epinephrine, which stimulates glycogenolysis. Catecholamines are the primary cause of elevated plasma glucose, and corticosteroids can contribute to the maintenance of glycemia (Oba et al., 2009), which provides energy for fish to escape, or to respond to other stressful situations (Wendelaar Bonga, 1997).
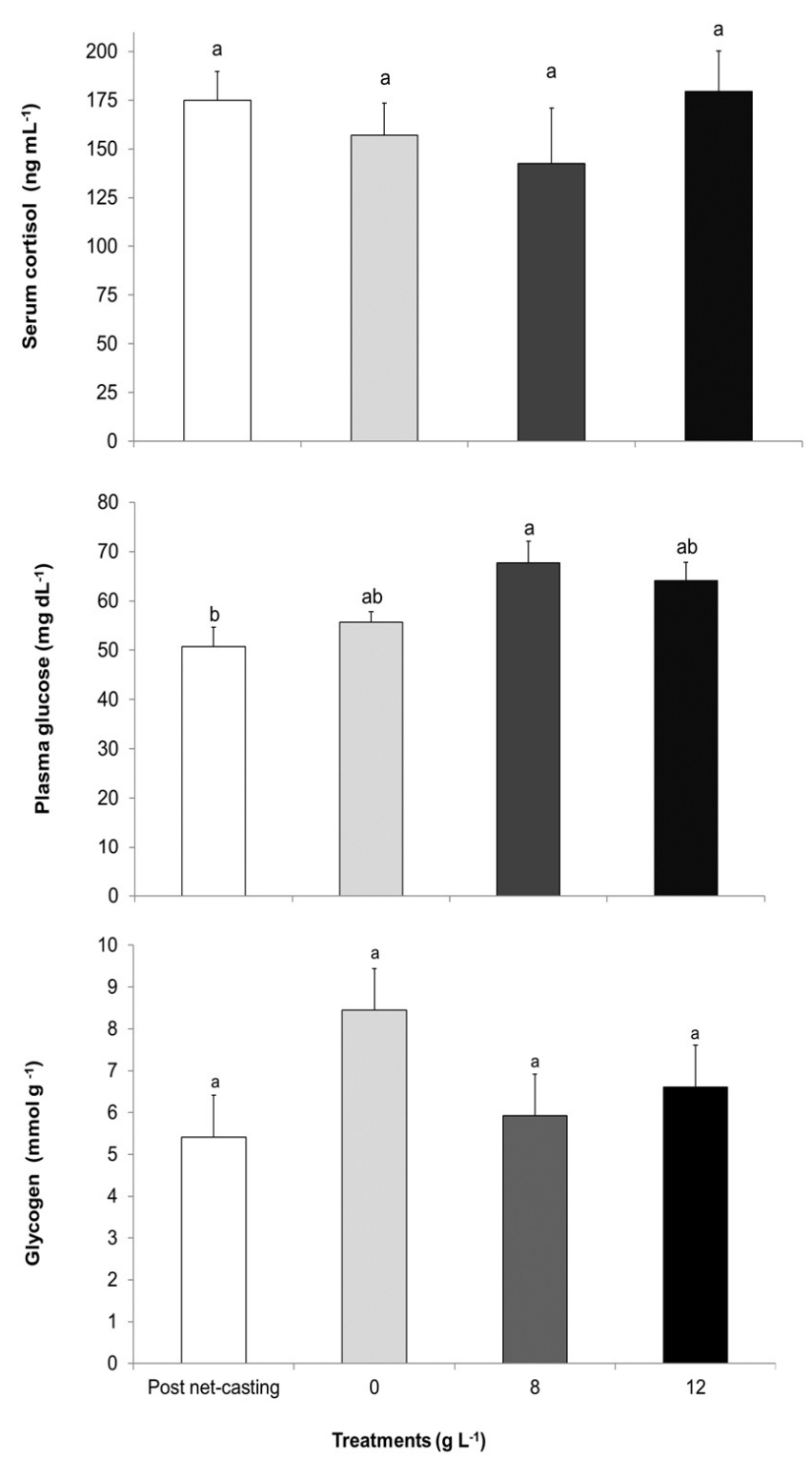

Figure 1. Mean serum cortisol, plasma glucose, and liver glycogen levels in non-transported silver catfish, fish transported without the addition of sodium chloride $(\mathrm{NaCl})$ to the water, and fish transported in water with the addition of $\mathrm{NaCl}$ at concentrations of 8.0 and $12.0 \mathrm{~g} \cdot \mathrm{L}^{-1}$. Vertical bars represent the standard error of the mean. Different letters indicate significant differences among treatments $(\mathrm{P}<0.05)$.
Increased levels of plasma glucose in fish transported in water containing $\mathrm{NaCl}$ have been reported by some authors. Carneiro \& Ubinati (2001), Urbinati et al. (2004), and Urbinati \& Carneiro (2006) observed increased plasma glucose levels in matrinxã (Brycon sp.) transported in water containing different concentrations of $\mathrm{NaCl}$. Gomes et al. (2006) found that the addition of $\mathrm{NaCl}$ at concentrations of $0,1,3$, and $5 \mathrm{~g} \cdot \mathrm{L}^{-1}$ to the transport water of pirarucu (Arapaima gigas) juveniles did not reduce plasma glucose levels.

Conversely to the increase in cortisol levels in the blood, liver glycogen levels are inversely proportional to stress levels (Mazeaud et al., 1977). When the plasma glucose is increased in response to stress, the glycogen reserves in the liver are reduced. In the present study, the low glucose levels may be related to the low levels of glycogen observed in the liver under all treatments (Figure 1). Thus, these results indicate that despite the occurrence of an initial stress response to the catching procedure, the energy reserves were too low to promote an elevation in the plasma glucose level.

The analysis of serum ions (Figure 2) revealed higher levels of sodium in fish transported in salt water $\left(8.0\right.$ and $\left.12.0-\mathrm{g} \mathrm{NaCl} \mathrm{L}^{-1}\right)$ than in those transported in $0-\mathrm{g} \mathrm{NaCl} \mathrm{L}^{-1}$. Fish transported in water containing $12.0-\mathrm{g} \mathrm{NaCl} \mathrm{L}^{-1}$ had a lower concentration of plasma chloride. However, there was no significant difference $(P>0.05)$ in the potassium levels in fish following all evaluated treatments. Fish transported in water containing salt $\left(8.0\right.$ and $\left.12.0-\mathrm{g} \mathrm{NaCl} \mathrm{L}^{-1}\right)$ showed higher calcium content than the non-transported fish $(P<0.05)$.

Determination of changes in serum ion levels is important to evaluate stress in fish, because during this process it becomes more difficult to maintain osmotic homeostasis. Such alterations may have occurred due to increased exposure of the branchial epithelium to the ionic gradient and are considered as secondary stress responses. Secreted hormones increase the permeability of the branchial epithelium, which leads to osmotic imbalance in freshwater fish (Bendhack \& Urbinati, 2009). Osmotic and ionic disorders may occur as a result of diuresis and the loss of blood electrolytes (Oba et al., 2009).

The $\mathrm{NaCl}$ presence in water used for transportation might cause an imbalance between the internal and external media of the fish because of increased membrane permeability, thus facilitating the influx of $\mathrm{NaCl}$ by osmosis from the external milieu, which in turn increases the serum sodium level in the animals, confirming that fish were not able to adapt to these high $\mathrm{NaCl}$ levels. Increase in sodium levels in whole fish's body was observed by Gomes et al. (1999) in silver catfish transported in water containing 6-g NaCl L-1, wherein animal mortality occurred after $12 \mathrm{~h}$ of transport. Wang et al. (2007) studied the effect of addition of different concentrations of $\mathrm{NaCl}\left(0,2,4,6\right.$ and $\left.8 \mathrm{~g} / \mathrm{L}^{-1}\right)$ in water production of Chalcalburnus chalcoides aralensis for 30 days and observed higher $\mathrm{Na}^{+}$serum concentrations in fish exposed to 4,6 and $8 \mathrm{~g} / \mathrm{L}^{-1} \mathrm{NaCl}$. The authors also observed higher $\mathrm{N}^{+}, \mathrm{K}^{+}$and ATPase levels in fish exposed to salinity than in the control fish. Gomes et al. (2006) also observed increased sodium influx in pirarucu (Arapaima gigas) juveniles transported for $3 \mathrm{~h}$ in water containing $\mathrm{NaCl}$ at concentrations of 1,3 , and $5 \mathrm{~g} \cdot \mathrm{L}^{-1}$. 

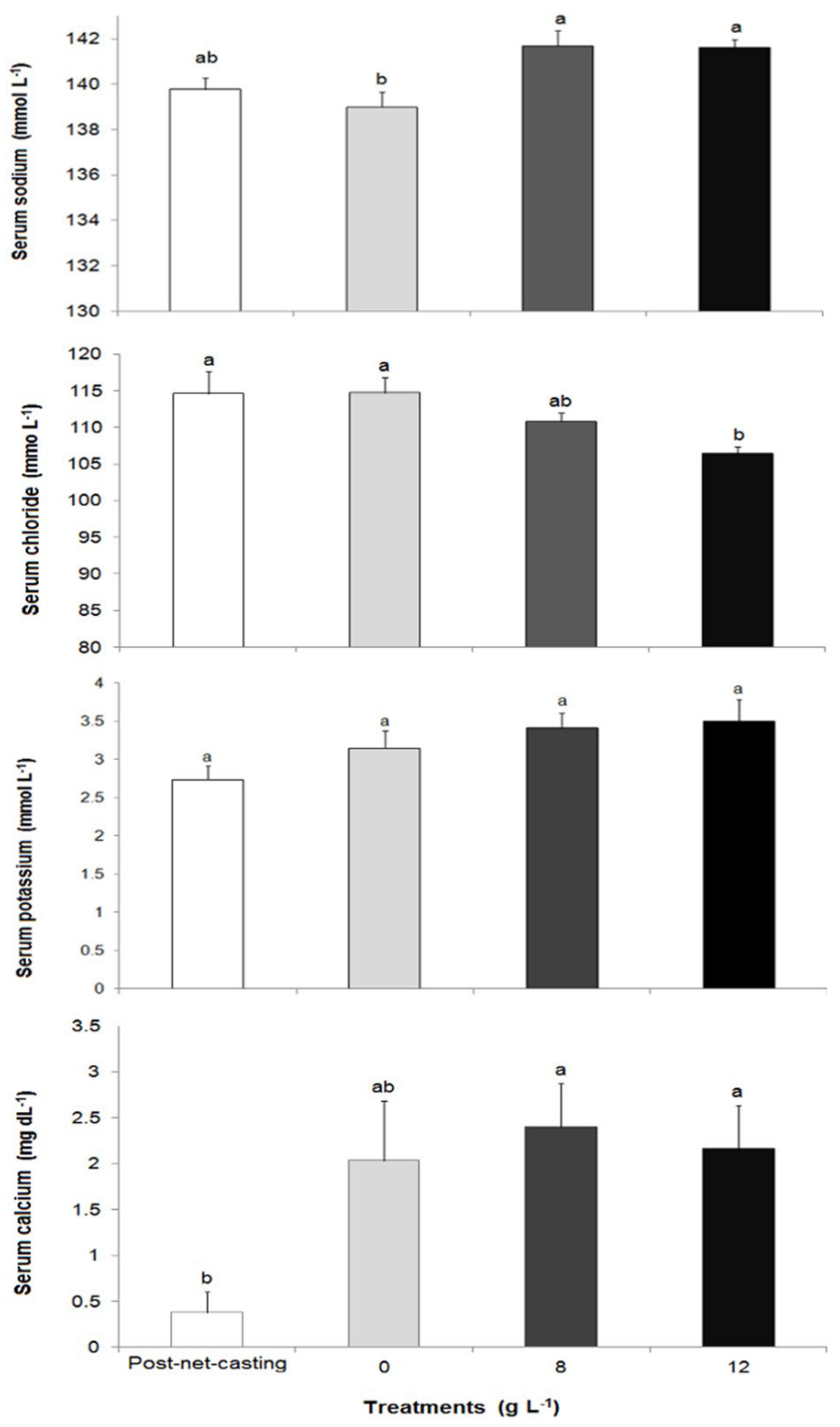

Figure 2. Mean serum concentrations of sodium, chloride, potassium, and calcium in non-transported silver catfish (post-net-casting), fish transported without the addition of sodium chloride $(\mathrm{NaCl})$ to the water (0), fish transported in water with the addition of $\mathrm{NaCl}$ at concentrations of $8.0(8)$ and $12.0 \mathrm{~g} \cdot \mathrm{L}^{-1}(12)$. Vertical bars represent the standard error of the mean. Different letters indicate significant differences among treatments $(\mathrm{P}<0.05)$.

Serum chloride levels showed the opposite trend to sodium levels. Serum chloride concentration in silver catfish decreased as the concentration of $\mathrm{NaCl}$ in transport water of fish increased. Different stress situations such as hypoxia, high osmolarity, physical exhaustion, high density and high or low temperature can cause ion imbalance in fish. Carneiro et al. (2009) observed no changes in the level of serum chloride in silver catfish transported in freshwater water (without added $\mathrm{NaCl}$ ) at different loading densities; whereas Urbinati et al. (2004) observed a reduction in serum chloride in matrinxã (Brycon sp.) juveniles after transportation in freshwater for $4 \mathrm{~h}$. Thus, indicating that electrolyte disturbances due to stress vary among species. The pattern in chloride and sodium levels observed in silver catfish suggests that possibly mechanisms regulating $\mathrm{Cl}$ - fluxes present some differences from those regulating $\mathrm{Na}+$ fluxes (Rosso et al., 2006).

Consistent with that observed in the current study, Carneiro \& Ubinati (2001) found no significant difference in the serum potassium content in matrinxã (Brycon cephalus) transported in water with different concentrations of $\mathrm{NaCl}$. However, they observed an increase in the serum potassium content in fish following transportation compared with baseline levels. This elevation was explained by the electrolytic disorder caused by stress in the animals as well as by the overflow of cell contents, wherein potassium is the main cation, due to increased fragility of the cells, as mentioned by Gomes et al. (2006), which observed an increase in $\mathrm{K}+$ influx at the highest $\mathrm{NaCl}$ concentration tested $(5 \mathrm{~g} / \mathrm{L})$.

It should be noted that, according to McDonald \& Milligan (1997), changes in the level of serum potassium, sodium, and chloride indicate that there is osmotic imbalance as a result of transport-induced stress. Thus, in the present experiment, increase in sodium, and decrease in chloride levels in the $\mathrm{NaCl}$ transported fish indicate an imbalance of cations and anions, respectively.

Evaluating stress during the transportation of matrinxãs (Brycon cephalus), Carneiro \& Ubinati (2001) found higher serum calcium contents in fish following transport, which corroborates the results of the present study, wherein the transported fish contained higher levels of calcium than the fish that were not transported. According to Wendelaar Bonga (1997), calcium helps to reduce gill membrane permeability, thereby decreasing ionic loss induced by catecholamines.

\subsection{Meat quality parameters}

Regarding the meat quality parameters, the interaction between treatment and storage time was significant only for redness $\left(\mathrm{a}^{*}\right)$ and count of psychrotrophic bacteria $(P<0.05)$.

There were no differences in the $\mathrm{pH}$ of the silver catfish muscle between treatments following different storage times. At $24 \mathrm{~h}$ post slaughter, $\mathrm{pH}$ decreased, varying from 6.41 to 6.46 , and showed a slight increase after $10 \mathrm{~d}$ of storage, when values ranged from $6.54\left(12.0\right.$ - $\left.\mathrm{g} \mathrm{NaCl} \mathrm{L}^{-1}\right)$ to $6.65\left(0-\mathrm{g} \mathrm{NaCl} \mathrm{L}^{-1}\right)$. In different lines of no-stressed North American catfish (Ictalurus punctatus and Ictalurus furcatus), $\mathrm{pH}$ of fillets at $24 \mathrm{~h}$ post slaughter has been reported ranging from 6.39 to 6.52 (Bosworth et al. 2004). Thus, $\mathrm{pH}_{24 \mathrm{~h}}$ of catfish of all treatments was within this range. The $\mathrm{pH}$ of fish meat during storage is considered an important meat quality parameter (Chomnawang et al., 2007). According to the Brazilian legislation (Brasil, 2017), the $\mathrm{pH}$ of the meat of fresh fish should be lower than 7.0. Considering the mean $\mathrm{pH}$ values found, the fish from all treatments maintained values within the limit for freshness $(<7.0)$ up to 10 days of storage on ice.

Regarding rigor mortis index, there were no differences among treatments over time, except for $16 \mathrm{~h}(960 \mathrm{~min})$ post mortem, for which non-transported group showed the lowest value $(P<0.05)$ (Figure 3$)$. However, fish transported in water containing $12.0-\mathrm{g} \mathrm{NaCl} \mathrm{L}^{-1}$ had its highest $\mathrm{RMI}$ value (100\%) at 


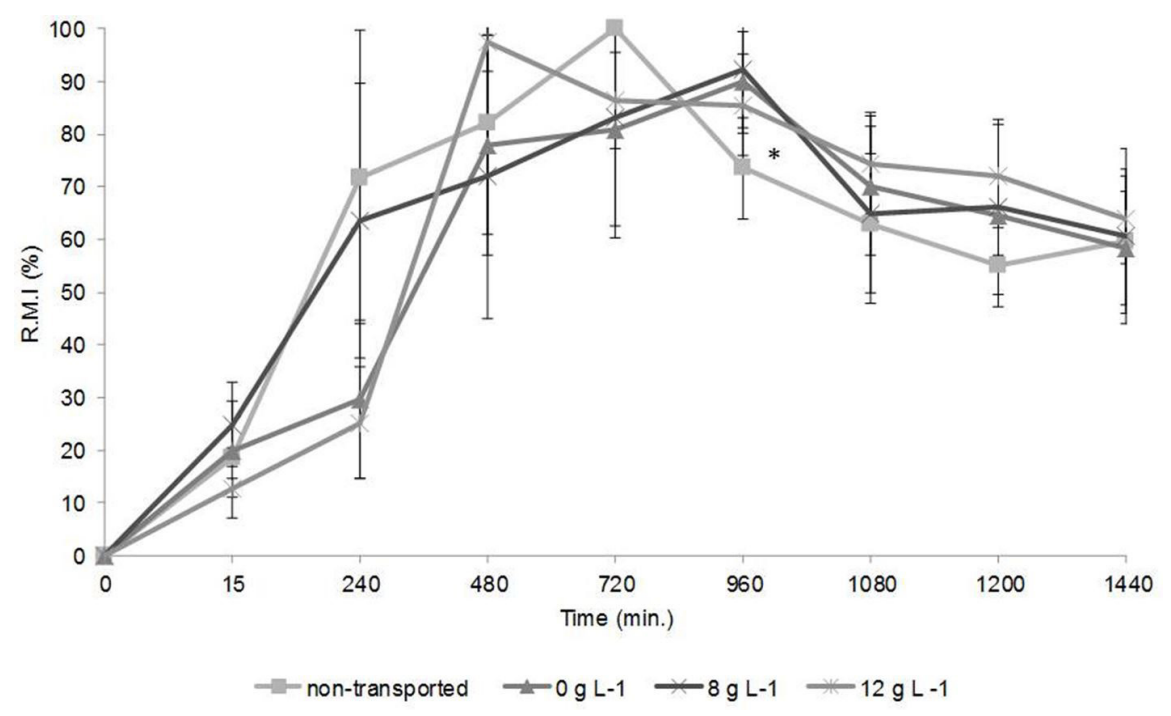

Figure 3. Evolution of the mean rigor mortis index (R.M.I) in non-transported silver catfish, fish transported without the addition of sodium chloride $(\mathrm{NaCl})$ to the water, and fish transported in water with the addition of $\mathrm{NaCl}$ at concentrations of 8.0 and $12.0 \mathrm{~g} \cdot \mathrm{L}^{-1}$ at $0,15,240,480,720,960,1080,1200$ and $1440 \mathrm{~min}$. postmortem in storage on ice. Vertical bars represent the standard deviation of the mean. *indicates significant differences among non-transported fish and 0,8 and $12 \mathrm{~g} \mathrm{~L}^{-1} \mathrm{NaCl}$ water transported fish $(\mathrm{P}<0.05)$.

$8 \mathrm{~h}$ (480 min) post mortem, indicating an earlier onset of full rigor mortis than in other treatments. Since there were no significant differences in serum cortisol levels among fish from different treatments and slaughter time, all fish were similarly stressed. The earlier onset of full rigor mortis in fish transported in water containing $12.0-\mathrm{g} \mathrm{NaCl} \mathrm{L}^{-1}$ indicates that this salt concentration might have affected rigor mortis evolution in those fish. The onset of rigor mortis has a decisive impact on shelf life of fresh fish (Skjervold et al., 1999), once it's related to post-mortem autolytic and bacterial decomposition. Consequently, a prolongation of rigor mortis period is of great economic importance.

Mikos (2011) observed a significant difference in the time taken for full rigor mortis development in tilapia (Oreochromis niloticus) transported in water with different $\mathrm{NaCl}$ concentrations. Similarly, tilapia transported with highest concentration of $\mathrm{NaCl}$ (1.2\%) reached rigor mortis in longer time (18-24h post-slaughter) than untransported fish (6-9h post-slaughter) or those transported in the presence of lower $\mathrm{NaCl}$ concentrations ( 0 and $0.9 \%$ ) (12-18h). These variations in the time taken for full rigor mortis develop in fish can be influenced, among other factors, by animal species and by their salt sensitivity.

Addition of $\mathrm{NaCl}$ on transport water did not affect lightness $\left(L^{*}\right)$ of fish meat between treatments $(P>0.05)$. However, storage time showed influence on the lightness of meat which became paler over storage time in all treatments $(P<0.05)$. The increase in meat lightness during storage was also reported by Veit et al. (2016) in catfish fillets, by Vargas et al. (2013) in matrinxã (Brycon cephalus) and by Santos (2013) in Nile tilapia (Oreochromis niloticus).

Treatment had effect on redness $\left(\mathrm{a}^{*}\right)$ and on color saturation $\left(C^{\star}\right)(P<0.05)$. Meat of silver catfish transported in 12.0 -g NaCl L ${ }^{-1}$ water displayed greater saturation of red color as compared to other $\mathrm{NaCl}$ treatments (Table 2). Occurrence of red color defect in catfish fillet is primarily attributed to over-abundance of hemoglobin, which could be a possible after-effect of pre-harvest stress factors (Desai et al., 2014). It should be noted that silver catfish meat is known for its white color. Thus, reddish meat decreases quality perception and acceptance by consumer. Treatment had no effect on yellowness $\left(b^{\star}\right)$ neither on hue, indicating no shifts in color between treatments over time toward discoloration (American Meat Science Association, 2012).

Regarding psychrotrophic bacteria count in silver catfish fillets, the significant interaction between treatment and storage time $(P=0.00)$ indicates that the increase of the salt concentration in the transport water and the storage time increased the count of psychrotrophic bacteria in fish (Table 3).

The population of aerobic microorganisms in fresh fish should not exceed 7.0 log CFU.g ${ }^{-1}$ for it to be considered suitable for consumption (International Commission on Microbiological Specifications for Food, 1986; Food and Agriculture Organization of the United Nations, 1997). Considering this value, the number of psychrotrophs in the post-net-casting group was close to this limit $\left(6.82 \log \mathrm{CFU} \cdot \mathrm{g}^{-1}\right)$ after 10 -days of storage in boxes with ice. In groups transported in water without added salt, with 8.0 and $12.0-\mathrm{g} \mathrm{NaCl} \mathrm{L}^{-1}$; however, the counts were $5.91,6.42$, and $6.48 \mathrm{log} \mathrm{CFU} \cdot \mathrm{g}^{-1}$, respectively, after 10 -days of storage on ice. Therefore, the psychrotrophic count in the fish from all treatments remained within the limit considered suitable for human consumption during the entire storage period.

Regards to the results of the sensory evaluation (Table 4 ), there was a significant difference between the treatments $(P<0.05)$ only at $96 \mathrm{~h}$ (4 days), and the scores given to the untransported and to the group transported in water without $\mathrm{NaCl}$ which was greater than those for the group exposed to $8.0-\mathrm{g} \mathrm{NaCl}(P<0.05)$, however this difference disappeared over time. After 10-days of storage, the silver catfish from all treatment groups received an 
Table 2. Mean values for redness $\left(\mathrm{a}^{\star}\right)$ and $\left(\mathrm{C}^{\star}\right)$ in silver catfish fillet immediately after net casting (non-transported) and silver catfish transported without $\mathrm{NaCl}$, with the addition of $8-\mathrm{g} \mathrm{NaCl} \mathrm{L}^{-1}$, and with the addition of $12-\mathrm{g} \mathrm{NaCl} \mathrm{L}^{-1}$ dissolved in water at $0,48,96,144,192$, and $240 \mathrm{~h}$ postmortem in storage on ice. (Mean \pm Standard Deviation).

\begin{tabular}{|c|c|c|c|c|c|}
\hline \multirow{2}{*}{ Time (h) } & Non-transported & $0 \mathrm{~g} \mathrm{NaCl} \mathrm{L}^{-1}$ & $8 \mathrm{~g} \mathrm{NaCl} \mathrm{L}^{-1}$ & $12 \mathrm{~g} \mathrm{NaCl} \mathrm{L}^{-1}$ & \multirow{2}{*}{ Mean } \\
\hline & \multicolumn{4}{|c|}{$a^{*}$} & \\
\hline 0 & $8.15 \pm 1.82^{\mathrm{aA}}$ & $5.42 \pm 2.32^{\mathrm{aA}}$ & $6.67 \pm 4.9^{\mathrm{aA}}$ & $3.92 \pm 1.2^{\mathrm{aC}}$ & $6.03 \pm 2.97^{\mathrm{A}}$ \\
\hline 48 & $5.49 \pm 0.98^{\mathrm{aAB}}$ & $3.65 \pm 0.84^{\mathrm{aAB}}$ & $3.07 \pm 2.56^{\mathrm{aA}}$ & $5.43 \pm 1.8^{\mathrm{aBC}}$ & $4.401 .82^{\mathrm{A}}$ \\
\hline 96 & $3.73 \pm 0.20^{\mathrm{bB}}$ & $4.95 \pm 1.23^{\mathrm{bAB}}$ & $2.62 \pm 0.6^{\mathrm{bA}}$ & $8.81 \pm 2.33^{\mathrm{aA}}$ & $5.022 .70^{\mathrm{A}}$ \\
\hline 144 & $6.83 \pm 1.43^{\mathrm{aAB}}$ & $2.43 \pm 0.14^{\mathrm{bB}}$ & $4.31 \pm 2.28^{\mathrm{abA}}$ & $5.65 \pm 2.25^{\mathrm{abABC}}$ & $4.802 .26^{\mathrm{A}}$ \\
\hline 192 & $5.30 \pm 3.16^{\mathrm{aAB}}$ & $3.03 \pm 1.56^{\mathrm{aAB}}$ & $2.25 \pm 0.9^{\mathrm{aA}}$ & $5.57 \pm 2.44^{\mathrm{aABC}}$ & $4.032 .38^{\mathrm{A}}$ \\
\hline 240 & $4.04 \pm 1.71^{\mathrm{bB}}$ & $2.84 \pm 1.67^{\mathrm{bAB}}$ & $3.33 \pm 1.6^{\mathrm{bA}}$ & $7.43 \pm 0.71^{\mathrm{aAB}}$ & $4.412 .26^{\mathrm{A}}$ \\
\hline Mean & $5.58 \pm 1.68^{\mathrm{a}}$ & $3.72 \pm 1.21^{\mathrm{b}}$ & $3.70 \pm 1.61^{\mathrm{b}}$ & $6.13 \pm 1.72^{\mathrm{a}}$ & \\
\hline Time $(\mathrm{h})$ & \multicolumn{4}{|c|}{$\mathrm{C}^{*}$} & \\
\hline 0 & $9.59 \pm 2.27^{\mathrm{aA}}$ & $7.93 \pm 1.99^{\mathrm{aA}}$ & $8.85 \pm 4.37^{\mathrm{aA}}$ & $6.51 \pm 2.64^{\mathrm{aB}}$ & \\
\hline 48 & $7.69 \pm 1.13^{\mathrm{abA}}$ & $6.12 \pm 0.41^{\mathrm{abA}}$ & $5.88 \pm 1.96^{\mathrm{bA}}$ & $8.39 \pm 1.31^{\mathrm{aAB}}$ & \\
\hline 96 & $7.75 \pm 1.8^{\mathrm{abA}}$ & $7.75 \pm 2.68^{\mathrm{abA}}$ & $4.74 \pm 0.54^{\mathrm{bA}}$ & $10.66 \pm 2.54^{\mathrm{aA}}$ & \\
\hline 144 & $9.62 \pm 1.75^{\mathrm{aA}}$ & $6.64 \pm 0.49^{\mathrm{aA}}$ & $7.12 \pm 2.7^{\mathrm{aA}}$ & $9.39 \pm 0.91^{\mathrm{aAB}}$ & \\
\hline 192 & $9.32 \pm 1.59^{\mathrm{aA}}$ & $7.04 \pm 0.46^{\mathrm{abA}}$ & $5.39 \pm 1.35^{\mathrm{bA}}$ & $8.19 \pm 1.35^{\mathrm{aAB}}$ & \\
\hline 240 & $7.80 \pm 0.99^{\mathrm{bA}}$ & $6.94 \pm 1.58^{\mathrm{bA}}$ & $6.50 \pm 0.82^{\mathrm{bA}}$ & $10.40 \pm 1.35^{\mathrm{aA}}$ & \\
\hline
\end{tabular}

Different lowercase letters indicate significant differences among treatments in each period $(P<0.05)$. Different uppercase letters indicate significant differences among times in the same treatment $(P<0.05)$.

Table 3. Mean counts of psychrotrophic aerobic bacteria (log CFU.g ${ }^{-1}$ ) in silver catfish immediately after net casting (non-transported) and silver catfish transported without $\mathrm{NaCl}$, with the addition of 8-g NaCl L ${ }^{-1}$, and with the addition of $12-\mathrm{g} \mathrm{NaCl} \mathrm{L}^{-1}$ dissolved in water at $0,48,96,144,192$, and $240 \mathrm{~h}$ postmortem in storage on ice. (Mean \pm Standard Deviation).

\begin{tabular}{ccclcc}
\hline Time $(\mathrm{h})$ & Non-transported & $0 \mathrm{~g} \mathrm{NaCl} \mathrm{L}^{-1}$ & $8 \mathrm{~g} \mathrm{NaCl} \mathrm{L}^{-1}$ & $12 \mathrm{~g} \mathrm{NaCl} \mathrm{L}^{-1}$ & $\mathrm{Mean}^{\mathrm{a}}$ \\
\hline 0 & $2.00 \pm 0.00^{\mathrm{aD}}$ & $2.00 \pm 0.00^{\mathrm{aB}}$ & $2.00 \pm 0.00^{\mathrm{aD}}$ & $2.00 \pm 0.00^{\mathrm{aE}}$ & $2.0 \pm 0.00^{\mathrm{D}}$ \\
48 & $2.98 \pm 0.03^{\mathrm{bC}}$ & $2.35 \pm 0.07^{\mathrm{bB}}$ & $2.35 \pm 0.07^{\mathrm{bCD}}$ & $4.33 \pm 0.30^{\mathrm{aD}}$ & $3.00 \pm 0.87^{\mathrm{C}}$ \\
96 & $3.70 \pm 0.07^{\mathrm{aC}}$ & $2.46 \pm 0.65^{\mathrm{aB}}$ & $3.33 \pm 0.38^{\mathrm{aC}}$ & $3.86 \pm 0.16^{\mathrm{aCD}}$ & $3.33 \pm 0.64^{\mathrm{C}}$ \\
144 & $5.09 \pm 0.43^{\mathrm{aB}}$ & $5.12 \pm 0.98^{\mathrm{aA}}$ & $4.63 \pm 0.45^{\mathrm{aB}}$ & $5.04 \pm 0.43^{\mathrm{aBC}}$ & $4.97 \pm 0.51^{\mathrm{B}}$ \\
192 & $6.25 \pm 0.21^{\mathrm{aA}}$ & $4.89 \pm 0.08^{\mathrm{cA}}$ & $4.94 \pm 0.07^{\mathrm{cB}}$ & $5.56 \pm 0.11^{\mathrm{bAB}}$ & $5.41 \pm 0.59^{\mathrm{B}}$ \\
240 & $6.82 \pm 0.00^{\mathrm{aA}}$ & $5.91 \pm 0.06^{\mathrm{cA}}$ & $6.42 \pm 0.07^{\mathrm{bA}}$ & $6.48 \pm 0.03^{\mathrm{bA}}$ & $6.40 \pm 0.35^{\mathrm{A}}$ \\
Mean & $4.47 \pm 1.81^{\mathrm{a}}$ & $3.78 \pm 1.66^{\mathrm{b}}$ & $3.94 \pm 1.62^{\mathrm{b}}$ & $4.54 \pm 1.48^{\mathrm{a}}$ & \\
\hline
\end{tabular}

Different lowercase letters indicate significant differences among treatments in each period $(P<0.05)$. Different uppercase letters indicate significant differences among times in the same treatment $(P<0.05)$.

Table 4. Mean sensory evaluation values obtained during the storage of silver catfish immediately after net casting (non-transported) and silver catfish transported without $\mathrm{NaCl}$, with $8-\mathrm{g} \mathrm{NaCl} \mathrm{L}^{-1}$, and with 12-g NaCl L${ }^{-1}$ dissolved in the water. (Mean \pm Standard Deviation).

\begin{tabular}{cclll}
\hline Time $(\mathrm{h})$ & Non-transported & $0 \mathrm{~g} \mathrm{NaCl} \mathrm{L}$ & $8 \mathrm{~g} \mathrm{NaCl} \mathrm{L}^{-1}$ & $12 \mathrm{~g} \mathrm{NaCl} \mathrm{L}^{-1}$ \\
\hline 0 & $5.00 \pm 0.00^{\mathrm{aA}}$ & $5.00 \pm 0.00^{\mathrm{aA}}$ & $5.00 \pm 0.00^{\mathrm{aA}}$ & $4.78 \pm 0.44^{\mathrm{aA}}$ \\
48 & $3.29 \pm 0.68^{\mathrm{aB}}$ & $3.56 \pm 0.88^{\mathrm{aB}}$ & $3.56 \pm 0.52^{\mathrm{aB}}$ & $3.78 \pm 0.66^{\mathrm{aB}}$ \\
96 & $3.00 \pm 0.00^{\mathrm{aBC}}$ & $2.91 \pm 0.54^{\mathrm{abB}}$ & $2.09 \pm 0.54^{\mathrm{cC}}$ & $2.14 \pm 0.38^{\mathrm{bcC}}$ \\
144 & $2.25 \pm 0.86^{\mathrm{aCD}}$ & $2.75 \pm 0.71^{\mathrm{aB}}$ & $2.38 \pm 0.91^{\mathrm{aCD}}$ & $2.08 \pm 0.79^{\mathrm{aC}}$ \\
192 & $2.33 \pm 0.51^{\mathrm{aCD}}$ & $1.80 \pm 0.79^{\mathrm{aC}}$ & $2.00 \pm 0.66^{\mathrm{aCD}}$ & $2.00 \pm 0.63^{\mathrm{aC}}$ \\
240 & $1.50 \pm 0.53^{\mathrm{aD}}$ & $1.63 \pm 0.52^{\mathrm{aC}}$ & $1.38 \pm 0.52^{\mathrm{aD}}$ & $1.58 \pm 0.67^{\mathrm{aC}}$ \\
\hline
\end{tabular}

Different lowercase letters indicate significant differences among treatments in each period $(P<0.05)$. Different uppercase letters indicate significant differences among times in the same treatment $(P<0.05)$.

average score of 1-2 on the freshness, mainly attributed to the appearance and the shape of the eyes, which were cloudy and sunken and to the flaccid texture of the fish body.

Santos (2011) conducted a study in which acoupa weakfish (Cynoscion acoupa) quality was evaluated, founding that this specie remained suitable for consumption until $8^{\text {th }}$ day of ice storage. Borges et al. (2013) evaluating pacu (Piaractus mesopotamicus), concluded that this specie showed an expiration date of 11 days when stored on ice. Almeida et al. (2006) in turn, found that tambaqui (Colossoma macropomum) stored on ice for up to 43 days retained sensory quality that would allow its commercialization. The scores received at the end of each storage period demonstrate that although count of psychrotrophs and $\mathrm{pH}$ values were within the limits, the silver catfish displayed reduced freshness. 


\section{Conclusion}

The use of $\mathrm{NaCl}$ in transport water at the tested concentrations (8.0 and 12.0- $\mathrm{g} \mathrm{L}^{-1}$ ) did not mitigate stress in adult silver catfish. Additionally, $\mathrm{NaCl}$ at $12.0 \mathrm{-g} \mathrm{L}^{-1}$ concentration was not favorable for catfish homeostasis, since it has contributed to an earlier onset of full rigor mortis and had a negative impact on the meat quality of fish. Thus, high concentrations of $\mathrm{NaCl}$ are not recommended for transport water of silver catfish.

\section{Ackowledgements}

The authors thank the Paraná Foundation for Research (Fundação Araucária), Program 014/2009, for the financial support.

\section{References}

Almeida, N. M., Batista, G. M., Kodaira, M., \& Lessi, E. (2006). Alterações pós-mortem em tambaqui (Colossoma macropomum) conservados em gelo. Ciência Rural, 36(4), 1288-1293. http://dx.doi.org/10.1590/ S0103-84782006000400038.

American Meat Science Association - AMSA. (2012). Meat color measurement guidelines. Illinois: AMSA.

Barcellos, L. G., Souza, S. M. G., \& Lucero, L. F. (1997). Estudos preliminares sobre o cortisol sérico em resposta ao estresse na tilápia-do-Nilo (Oreochromis niloticus). Boletim do Instituto de Pesca, 24, 239-245.

Becker, A. G., Parodi, T. V., Heldwein, C. G., Zeppenfeld, C. C., Heinzmann, B. M., \& Baldisserotto, B. (2012). Transportation of silver catfish, Rhamdia quelen in water with eugenol and the essential oil of Lippia alba. Fish Physiology and Biochemistry, 38(3), 789-796. http://dx.doi.org/10.1007/s10695-011-9562-4. PMid:21972065.

Bendhack, F., \& Urbinati, E. C. (2009). Mitigating stress effects during transportation of matrinxã (Brycon amazonicus Günther, 1869; Characidae) through the application of calcium sulfate. Journal of Applied Ichthyology, 25(2), 201-205. http://dx.doi.org/10.1111/j.14390426.2008.01208.x.

Bito, M., Yamada, K., Mikumo, Y., \& Amano, K. (1983). Studies on rigor mortis of fish - I. Difference in the mode of rigor mortis among some varieties of fish. By modified Cutting's methods. Bulletin of Tokai Regional Fisheries Research Laboratory, 109, 89-96.

Borges, A., Conte-Junior, C. A., Franco, R. M., \& Freitas, M. Q. (2013). Quality Index Method (QIM) developed for pacu Piaractus mesopotamicus and determination of its shelf life. Food Research International, 54(1), 311-317. http://dx.doi.org/10.1016/j.foodres.2013.07.012.

Bosworth, B. G., Wolters, W. R., Silva, J., Chamul, R., \& Park, S. (2004). Comparison of production, meat yield, and meat quality traits of NWAC103 line channel catfish, Norris line channel catfish, and female channel catfish x male blue catfish F1 hybrids. North American Journal of Aquaculture, 66(3), 177-183. http://dx.doi. org/10.1577/A03-032.1.

Brandão, F. R., Gomes, L. C., Crescencio, R., \& Carvalho, E. S. (2008). Uso de sal durante o transporte de juvenis (1 kg) de pirarucu (Arapaima gigas). Acta Amazonica, 38(4), 767-771. http://dx.doi. org/10.1590/S0044-59672008000400022.

Brasil, Ministério da Agricultura Pecuária e do Abastecimento. (2003, Agosto 26). Oficializa os Métodos Analíticos Oficiais para Análises Microbiológicas para Controle de Produtos de Origem Animal e Água (Instrução Normativa n ${ }^{\circ}$ 62, de 26 de agosto de 2003). Diário Oficial [da] República Federativa do Brasil.
Brasil, Ministério da Agricultura Pecuária e do Abastecimento. (2017, Março 29). Regulamento de Inspeção Industrial e Sanitária de Produtos de Origem Animal (Decreto n 9.013, de 29 de março de 2017). Diário Oficial [da] República Federativa do Brasil.

Carneiro, P. C. F., \& Mikos, J. D. (2005). Frequência alimentar e crescimento de alevinos de jundiá, Rhamdia quelen. Ciência Rural, 35(1), 187-191. http://dx.doi.org/10.1590/S0103-84782005000100030.

Carneiro, P. C. F., \& Ubinati, E. C. (2001). Salt as a stress response mitigator of matrinxã Brycon cephalus (Teleostei: Characidae) during transport. Aquaculture Research, 32(4), 297-304. http:// dx.doi.org/10.1046/j.1365-2109.2001.00558.x.

Carneiro, P. C. F., Kaiseler, P. H. S., Swarofsky, E. A. C., \& Baldisserotto, B. (2009). Transport of jundiá Rhamdia quelen juveniles at different loading densities: water quality and blood parameters. Neotropical Ichthyology, 7(2), 283-288. http://dx.doi.org/10.1590/S167962252009000200021 .

Carneiro, P. C. F., Mikos, J. D., Bendhack, F. \& Ignácio, S. A. (2004). Processamento do jundiá Rhamdia quelen: rendimento de carcaça. Revista Acadêmica: Ciências Agrárias e Ambientais, 2(3), 11-17.

Chomnawang, C., Nantachai, K., Yongsawatdigul, J., Thawornchinsombut, S., \& Tungkawachara, S. (2007). Chemical and biochemical changes of hybrid catfish fillet stored at $4{ }^{\circ} \mathrm{C}$ and its gel properties. Food Chemistry, 103(2), 420-427. http://dx.doi.org/10.1016/j.foodchem.2006.07.039.

Copatti, C. E., Garcia, L. O., Kochhann, D., Cunha, M. A., \& Baldisserotto, B. (2011). Dietary salt and water $\mathrm{pH}$ effects on growth and $\mathrm{Na}^{+}$ fluxes of silver catfish juveniles. Acta Scientiarum, 33(3), 261-266.

Cunha, M. A., Zeppenfeld, C. C., Garcia, L. O., Loro, V. L., Fonseca, M. B., Emanuelli, T., Veeck, A. P. L., Copatti, C. E., \& Baldisserotto, B. (2010). Anesthesia of silver catfish with eugenol: time of induction, cortisol response and sensory analysis of fillet. Ciência Rural, 40(10), 2107-2114. http://dx.doi.org/10.1590/S0103-84782010001000009.

Desai, M. A., Joseph, P., Suman, S. P., Silva, J. L., Kim, T., \& Schilling, M. W. (2014). Proteome basis of red color defect in channel catfish (Ictalurus punctatus) fillets. Food Science and Technology, 57, 141-148.

Food and Agriculture Organization of the United Nations - FAO. (1986). The transport of live fish a review. Rome: European Inland Fisheries Advisory Commission.

Food and Agriculture Organization of the United Nations - FAO. (1997). Aseguramiento de la calidad de los productos pesqueros. Roma: Documento Tecnico de Pesca.

Fracalossi, D. M., Meyer, G. M., Santamaria, F. M., Weingartner, E., \& Zaniboni-Filho, M. (2004). Desempenho do jundiá, Rhamdia quelen, e do dourado, Salminus brasiliensis, em viveiros de terra na região sul do Brasil. Acta Scientiarum. Animal Sciences, 26(3), 345-352. http://dx.doi.org/10.4025/actascianimsci.v26i3.1806.

Golombieski, J. I., Silva, L. V. F., Baldisserotto, B., \& Silva, J. H. S. (2003). Transport of silver catfish (Rhamdia quelen) fingerlings at different times, load densities, and temperatures. Aquaculture, 216(1-4), 95102. http://dx.doi.org/10.1016/S0044-8486(02)00256-9.

Gomes, L. C., Araújo-Lima, C. A. R. M., Roubach, R., \& Urbinati, E. C. (2003). Avaliação dos efeitos da adição de sal e da densidade no transporte de tambaqui. Pesquisa Agropecuária Brasileira, 38(2), 283-290. http://dx.doi.org/10.1590/S0100-204X2003000200016.

Gomes, L. C., Chagas, E. C., Brinn, R. P., Roubach, R., Coppati, C. E., \& Baldisserotto, B. (2006). Use of salt during transportation of air breathing pirarucu juveniles (Arapaima gigas) in plastic bags. Aquaculture, 256(1-4), 521-528. http://dx.doi.org/10.1016/j. aquaculture.2006.02.004.

Gomes, L. C., Golombieski, J. I., Chippari-Gomes, A. R., \& Baldisserotto, B. (1999). Effect of salt in the water for transport on survival and on 
$\mathrm{Na}+$ and $\mathrm{K}+$ body levels of silver catfish, Rhamdia quelen, fingerlings. Journal of Applied Aquaculture, 9(4), 1-9. http://dx.doi.org/10.1300/ J028v09n04_01.

International Commission on Microbiological Specifications for Food - ICMSF. (1986). Sampling for microbiological analysis: Principles and specific applications (2nd ed.). Oxford: Blackwell Scientific Publications.

Mazeaud, M. M., Mazeaud, F., \& Donaldson, E. M. (1977). Primary and secondary effects of stress in fish: some new data with a general review. Transactions of the American Fisheries Society, 106(3), 201212. http://dx.doi.org/10.1577/1548-8659(1977)106<201:PASEO $\mathrm{S}>2.0 . \mathrm{CO} ; 2$.

McDonald, G., \& Milligan, L. (1997). Ionic, osmotic and acid-base regulation in stress. In G. W. Iwama, A. D. Pickering, J. P. Sumpter \& C. B. Schreck (Eds.), Fish stress and health in aquaculture (pp. 119-144). Cambridge: University Press.

Mikos, J. D. (2011). Efeito do transporte sobre o estresse e a qualidade da carne de Tilápia do Nilo (Oreochromis niloticus) (Dissertação de mestrado). Pontifícia Universidade Católica do Paraná, Curitiba.

Moon, T. W., Foster, G. D., \& Plisetskaya, E. M. (1989). Changes in peptide hormones and liver enzymes in the rainbow trout deprived of food for 6 weeks. Canadian Journal of Zoology, 67(9), 2189-2193. http://dx.doi.org/10.1139/z89-309.

Oba, E. T., Mariano, W. S., \& Santos, L. R. B. (2009). Estresse em peixes cultivados: agravantes e atenuantes para o manejo rentável. In M. Tavares-Dias (Ed.), Manejo e sanidade de peixes em cultivo (pp. 226-247). Embrapa Amapá, Macapá.

Pereira, C. R., Barcellos, L. J. G., Kreutz, L. C., Quevedo, R. M., Ritter, F., \& Silva, L. B. (2006). Embryonic and larval development of Jundiá (Rhamdia quelen, Quoy \& Gaimard, 1824, Pisces, Teleostei), A South American Catfish. Brazilian Journal of Biology = Revista Brasileira de Biologia, 66(4), 1057-1063. http://dx.doi.org/10.1590/ S1519-69842006000600013. PMid:17299942.

Rosso, F. L., Bolner, K. C. S., \& Baldisserotto, B. (2006). Ion fluxes in silver catfish (Rhamdia queelen) juveniles exposed to diferente dissolved oxigen levels. Neotropical Ichthyology, 4(4), 435-440. http:// dx.doi.org/10.1590/S1679-62252006000400007.
Santos, A. P. B. (2011). Índices químicos, sensoriais e microbiológicos para avaliação do frescor de pescada-amarela (Cynoscion acoupa) armazenada em gelo (Tese de doutorado). Universidade de São Paulo, São Paulo.

Santos, E. C. B. (2013). Métodos de abate e qualidade da tilápia do Nilo (Tese de doutorado). Universidade Estadual Paulista, Jaboticabal.

Skjervold, P. O., Fjaera, S. O., \& Ostby, P. B. (1999). Rigor in Atlantic salmon as affected by crowding stress prior to chilling before slaughter. Aquaculture, 175(1-2), 93-101. http://dx.doi.org/10.1016/ S0044-8486(99)00037-X.

Urbinati, E. C., \& Carneiro, P. C. F. (2006). Sodium chloride added to transport water and physiological responses of matrinxã Brycon amazonicus (Teleost: Characidae). Acta Amazonica, 36(4), 569-572. http://dx.doi.org/10.1590/S0044-59672006000400020.

Urbinati, E. C., Abreu, J. S., Silva-Camargo, A. C., \& Landinez-Parra, M. A. (2004). Loading and transport stress of juvenile matrinxã (Brycon cephalus, Characidae) at various densities. Aquaculture, 229(1-4), 389-400. http://dx.doi.org/10.1016/S0044-8486(03)00350-8.

Vargas, S. C., Oliveira-Filho, P. R. C., Natori, M. M., Lima, C. G., \& Viegas, E. M. M. (2013). Evaluation of different stunning methods on aspects of animal welfare and meat quality of matrinxã (Brycon cephalus). Italian Journal of Food Science, 25, 255-262.

Veit, J. C., Piccolo, J., Facco, G., Scherer, A. F., Baldisserotto, B., Koakoski, G., Menezes, C. C., Loro, V. L., Barcellos, L. J. G., Mello, R. O., \& Emanuelli, T. (2016). Influence of electronarcosis on behavioral responses, blood markers and fillet properties of silver catfish (Rhamdia quelen). Journal of Aquatic Food Product Technology, 26(3), 308-324. http://dx.doi.org/10.1080/10498850.2016.1170747.

Wang, X., Lin, Y., Jiang, Q., Geng, L., \& Liu, B. (2007). Effects of $\mathrm{NaCl}$ on Concentration of Serum Ions, Cortisol and Activities of $\mathrm{Na}$, $\mathrm{K}+$, ATPase on tissue in Chalcalburnus chalcoides aralensis. Journal of Jilin Agricultural University, 29(5), 917-924.

Wedemeyer, G. A., Barton, B. A., \& McLeay, D. J. (1990). Stress and acclimation. In: C. B. Schreck \& P. B. Moyle (Eds.), Methods for fish biology (pp. 451-489). Bethesda: American Fisheries Society.

Wendelaar Bonga, S. E. (1997). The stress response in fish. Physiological Reviews, 77(3), 591-625. http://dx.doi.org/10.1152/physrev.1997.77.3.591. PMid:9234959. 